\title{
CONSTRUCTING A NETWORK EVALUATION FRAMEWORK FOR IMPROVING THE FINANCIAL ECOSYSTEM IN SMALL-MEDIUM SIZE FIRMS
}

\author{
Cheng Shian LIN, Chun Yueh LIN* \\ CTBC Financial Management College, Tainan, Taiwan No. 600, Sec. 3 , \\ Taijiang Blvd., Annan District, Tainan, Taiwan 709, R.O.C. \\ Received 11 January 2015; accepted 23 January 2016
}

\begin{abstract}
This study presents an evaluation framework to measure the various operations to acquire the optimal core operation (CO) when financier provides the supply chain finance (SCF) services in smartphone industry supply chain (SC). The proposed model applies the modify Delphi method and analytic network process (ANP). First, the evaluation model establishes a network with three criteria, eleven sub-criteria and four operations. Next, the ANP is utilized to the framework to obtain the relative weights of the criteria. Finally, the application of the multi-criteria decision making process will list the optimal $\mathrm{CO}$ on the basis of their rankings in the framework.

The proposed model and the relevant research results can provide academic support to the decision-makers on finance sector with a valuable objective guide for assessing the CO of smartphone industry SC programs to determine the optimal solution in their actual administration of SCF service practices.
\end{abstract}

Keywords: Small-Medium Size Enterprise (SMEs), supply chain finance (SCF), core operation (CO), dependent relationship (DR), analytic network process (ANP), smartphone industry.

JEL Classification: C54, D71, E51.

\section{Introduction}

The modern economy has two defining characteristics: globalization and intense competition. This has led to many industries implementing supply chain management (SCM) in order to help maintain acceptable profitability in this intensely competitive market. SCM systems have recently raised a lot of interest since integrated management of a supply chain (SC) can lead to less uncertainties in the business ecosystem, thus can positively influence the profitability of all of the SC members and assist in the co-ordination of all of the input/output flows (materials, information and finances) (Simchi-Levi et al. 2000; Guillen et al. 2007).

*Corresponding author. E-mail: ljy898@gmail.com 
SCM systems depend on a variety of processes and activities including finance, manufacturing, logistics and marketing in order to properly coordinate the flow of goods, services and capital between individual stages in the supply chain (Blackman et al. 2013). It should be noted that financial processes are important to any industry that has implemented SC activities. This considered, financial organizations must examine Small-Medium sized Enterprises (SMEs) in a very careful way when providing them with the working capital required to expand their respective market shares. This concept is the basis of Supply Chain Finance (SCF) which can improve the efficiency of the flow of finance within the SC. The idea of SCF was proposed in 2006 (Berger, Udell 2006). Pfohl and Gomm (2009) expanded upon this first definition by outlining some of the details of SCF. They explained that SCF is the inter-company optimization of financing and further integration of the financing process into the broader ecosystem of customers, suppliers and service providers which increases the value of all participants overall. Randal and Farris (2009) later found that integration of SCF can strengthen the SC overall by collaborative management of the cash-to-cash cycle as well as balancing out the weighted average cost of capital amongst all participants. Thus SCF has the ability to create a fiscal win-win for all parties: the buyer, seller and financial intermediary (More, Basu 2013). In the opinion of the bank, the biggest advantage of SCF is the ability to find the core enterprise (CE) within the SC, thus improving the overall financial ecosystem based on the newfound efficiency from finding the CE. The efficiency is found because the good credit of the CE is extended to the upstream and downstream enterprises lifting the lid on lending without the addition of more unacceptable risk (Wang et al. 2013; Liu 2007).

The three flows of a standard SCM system (financial, goods and information) is shown in Figure 1 while Figure 2 shows the ecosystem of SCF. For instance, if the CE is the manufacturer, SC members (upstream/downstream) within the ecosystem can extend the CE credit to enhance the working capital efficiency, thus solving the problem most SMEs face when they have low credit availability to loan out funds. Therefore, the CE in a SCF ecosystem is a critical concept for banks to understand.

In the current model, financial institutions will separately loan funds to firms in each step of the supply chain. As an example, a manufacturer might send product to a retailer and receive an account payable promissory note which will be forwarded to a financial institution to allow the retailer to obtain credit to pay for the product. If the "CO" was found, a much more efficient model could be created where every member within the supply chain can use transaction records from upstream and downstream transactions to receive credit from the manufacturer. However, this involves a lot of risks through the core operation to other members in a supply chain when they have implemented the SCF activity into the ecosystem. The most important ones are SC systematic risk, transaction risk, as well as bankruptcy risk. That's why it is important for the financial institution to do its due diligence in evaluating the optimal CE when considering providing the SCF service. Thus far, there is no comprehensive body of research dedicated to CE evaluation in the SCF. This considered, finding the CO within the supply chain ecosystem is an important process and the subsequent evaluation of an optimal alternative is a multi-criteria issue and ideal model needs suitable factors and strict screening (Wu et al. 2007a). 


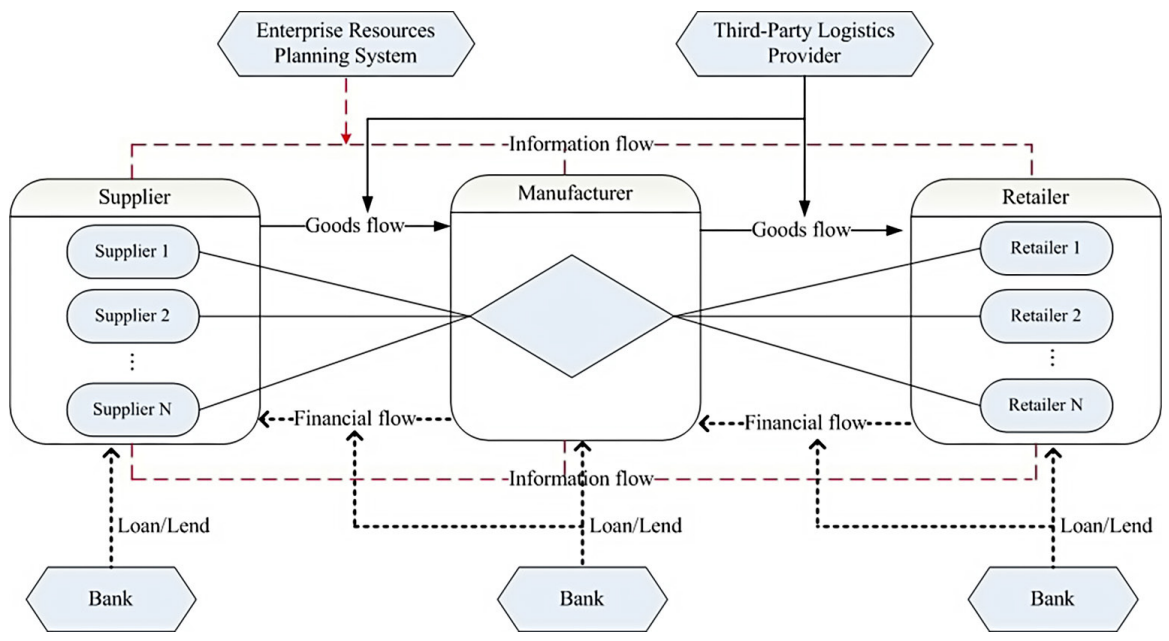

Fig. 1. The three flows of a traditional SCM system

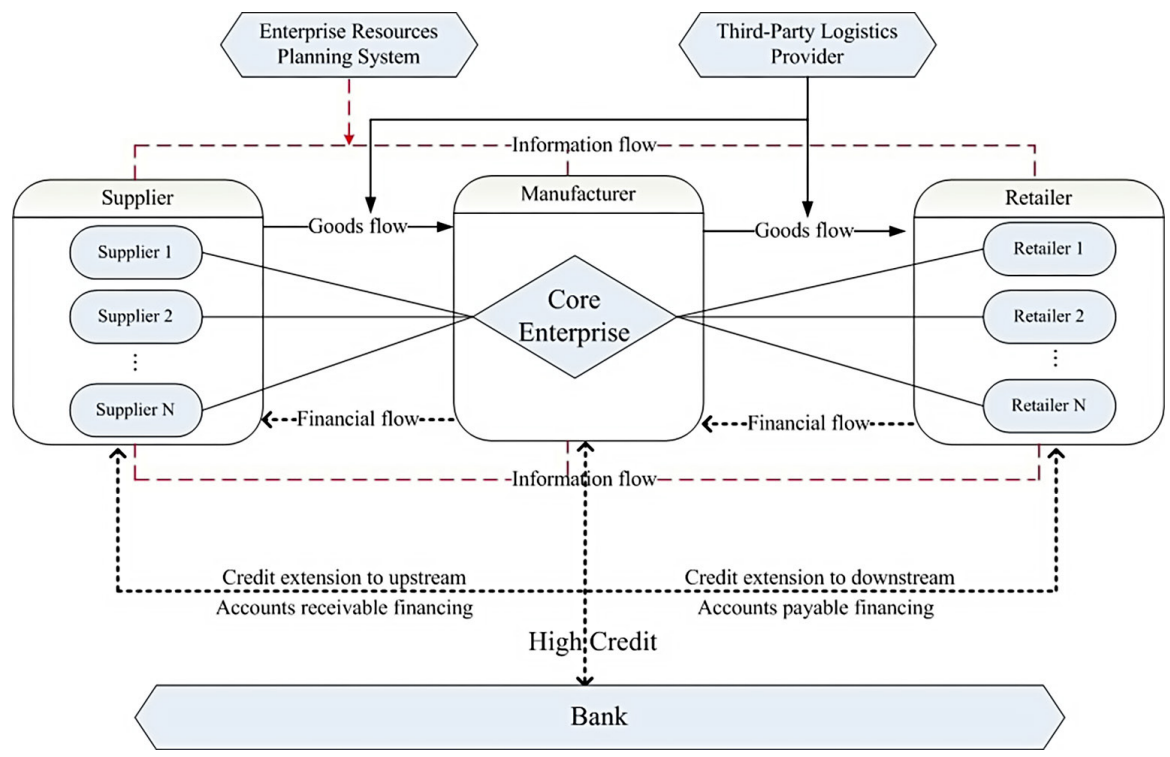

Fig. 2. The ecosystem of SCF

Furthermore, this study integrates the modify Delphi method as well as ANP to evaluate the synthetic utility values of criteria and sub-criteria weights and then ranking optimal $\mathrm{CO}$ in smartphone industry SC from the opinions of experts in the financial sector. Thus, the ANP based model of decision making is used to provide those in a decision making position or bank administrators with a highly valuable reference guide for the process of evaluating what exactly is the optimal CO when they are planning to create the SCF for the specific SC. 
In an academic context, the ANP-based model of decision making can provide those in the position of decision making in a bank or financial firm with valuable guidance for determining the optimal CO when planning to provide SCF services. In the commercial space, this evaluation model can then provide managers with a highly useful instrument to measure the optimal CO within the smartphone SC.

\section{Literature review}

\subsection{Supply chain finance}

The concept of supply chain finance (SCF) is a new issue in economic, finance and operation management scope. In a post-2008 economic environment, it is very difficult to access funds through traditional credit channels. Because banks are lending less, corporations are finding different ways to source funding. Insufficient access to required financing has strained a number of buyer/supplier relationships (Yan et al. 2016; More, Basu 2013). Thus the SCF ecosystem is an attempt to solve this problem for many SC members. The SCF ecosystem is a new type of financial service which has the ability to make the SC more efficient by providing SMEs in the system with a lower cost of credit. In addition, Kristofik et al. (2012) proposed the goal of SCF is to obtain visibility over processes, such as purchase-to-pay and order-to-cash cycles, as well as processes involved in ordering, invoicing, reconciliation and payment. That is able to create efficiencies, cost savings and investment opportunities throughout the chain (Kristofik et al. 2012). There are number of studies about the positive impact of banks providing the SCF service in the SC insofar that in enhances profitability, builds a richer collaborative relationship with clients, as well as increases the profile of the financial organization which leads to an expanded need for the banking service (MAZARS 2011; He, Tang 2012). Although there is a large body of research about the SCF that covers concrete coordination, working capital and optimal financial flow (Yan, Sun 2013; Kristofik et al. 2012; Pfohl, Gomm 2009) the work thus far has not solved the most important problem at the core of the SCF question which is: what exactly constitutes the "CO" of a supply chain. Determining what exactly the "CO" is within the industry supply chain is absolutely crucial to improving the efficiency of credit. The normal model, though this does not apply to all, in the SCF supply chain is that there is one big company sandwiched between two SMEs.

\subsection{Multi-criteria decision-making in smartphone industry supply chain}

This study is to present a new model and case study of the smartphone industry SC is to allow a bank to assess which operation is the optimal core operation (CO). The main process of the smartphone industry supply chain can be divided into the (1) components supplier, (2) Original equipment manufacturer /Original design manufacturer (OEM/ODM), (3) Brands and (4) Retailer/Telecom (Ali-Yrkko et al. 2011; Linden et al. 2009) as shown in Figure 3. The smartphone market was chosen for this particular case study because its SC is highly intricate and complex, thus finding the Core Operation, within the CE, in the smartphone market's SCF would allow for the SMEs in the supply chain to become more efficient through lower borrowing costs and thus erode the barrier to loans. 


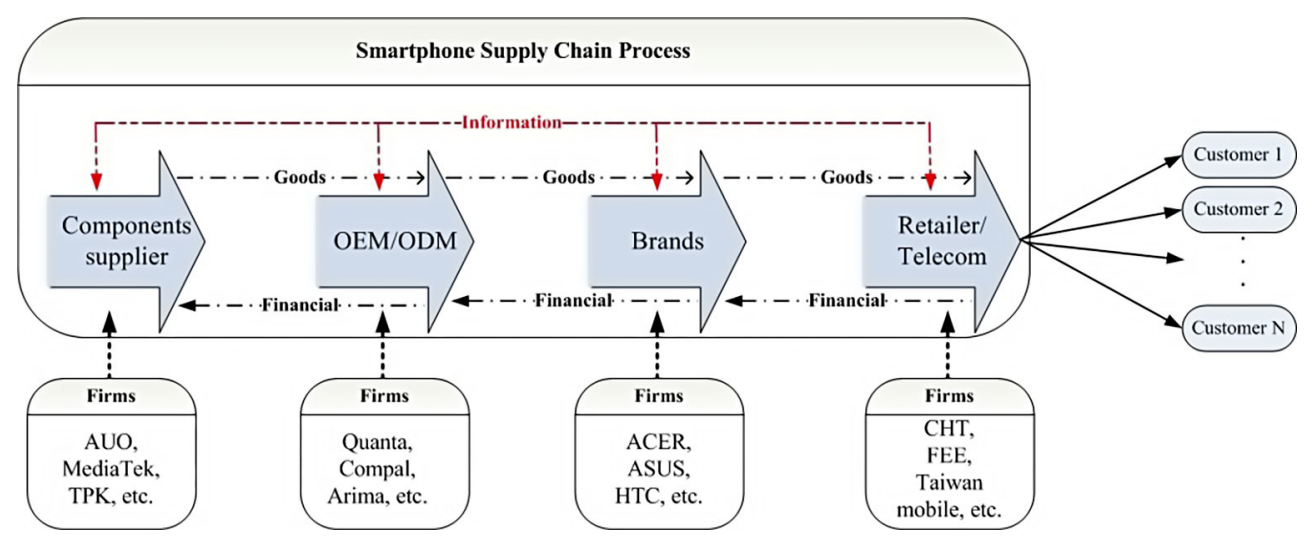

Fig. 3. The Smartphone industry SC process

Source: Ali-Yrkko et al. 2011; Linden et al. 2009

Within the smartphone industry supply chain, finding the CO can be difficult because often it is simply not obviously apparent. It's not obviously apparent because within the supply chain there are different sized firms, and the CO cannot be found without an in-depth comprehensive analysis. There is no "golden rule" in finding the CO, as it can be in any part of the supply chain which is why a comprehensive model is needed.

Looking back at previous literature, there has not been much published about the SCF and the smartphone industry which employed the multi-criteria decision-making (MCDM) concept in order to evaluate the optimal CO of the smartphone SC for a bank or financial institution. One of the things the MCDM problem relies heavily on the analytic hierarchy process (AHP). The AHP method is employed to prioritize and weigh each criterion and their alternatives (Tsai et al. 2010; Xu et al. 2015). In prior literature, there are a number of studies that have applied AHP to construct a hierarchical architecture to which MCDM topics can be structured (Adhikary et al. 2013; Ashis 2013; Shahin, Pourhamidi 2013; Yazdani-Chamzini et al. 2013). While AHP is popular, the algorithm itself cannot resolve the fundamental characteristic of feedback which is a dependent in the decision problem process.

Taking this into account, the study seeks to develop an evaluation framework which is based on ANP, and considers network prioritization and obtains the optimal CO. This study will utilize the modified Delphi method and the ANP, in addition to literate review and surveys of experts in the financial field, to construct an evaluation process which can estimate the optimal CO of a smartphone industry SC to make the complex situation clear for a potential financier. In the past, there have been some studies that have applied the ANP model to solve the feedback and dependent decision problem. Such as Uygun et al. (2015) used the fuzzy hybrid multi-criteria decision-making model and 7 variables for measuring the institutionalization readiness level of SMEs. Pourahmad et al. (2015) integrated the Fuzzy-AHP and DEMATEL-ANP for selecting the optimal space in leisure. Aragones-Beltran et al. (2014) used AHP and ANP model to select the solar-thermal power plant investment projects. Zaim et al. (2014) proposed an ANP framework to rank the 
technical characteristics of product. Theiben and Spinler (2014) developed an evaluation model to measure which supplier is the most suitable partner for implementation of a collaborative $\mathrm{CO} 2$ reduction and so on.

Moreover, this study synthesizes the modify Delphi method as well as ANP to determine the synthetic utility values of criteria and sub-criteria weights and then ranking optimal CO in smartphone industry SC from the opinions of experts in the financier.

\section{Evaluation Model}

The modified Delphi processes is applied here to collect experts' view and point out the determinants of the evaluation model and then calculation of the weighted criteria and rank using ANP. The processes of the evaluation model are follows.

\subsection{Delphi processes}

The Delphi processes collects and analyzes the results of anonymous experts who communicate by means of writing, discussion and feedback with respect to particular issues. Sharing the skills, knowledge, expertise, and opinions to them achieve a mutual consensus by experts (Sung 2001). The procedure of Delphi as follows (Wu et al. 2007b):
A. Selection of the anonymous and suitable specialist.
B. Execution of the first round of the survey.
C. Execution of the second round of the survey.
D. Execution of the third round of the survey.
E. Combination of the expert suggestion and achieve a consensus.

Stages C and D are normally repeated to a consensus is achieved regarding a particular topic (Sung 2001). The outcome of the previous literature reviews and expert interviews are able to synthesize and apply to the survey. Furthermore, stage B is simplified in order to change the conventionally utilized open style survey; when this is done it is commonly referred to as the modified Delphi processes (Sung 2001). This research constructs a quality evaluation factor for evaluating the $\mathrm{CO}$ in smartphone industry supply chain ecosystem based on the modified Delphi processes, and by conducting interviews with anonymous specialists.

\subsection{Analytic Network Process (ANP) methodology}

In 1996, Saaty proposed the method known as Analytic Network Process (ANP). ANP algorithm is extend from the Analytic Hierarchy Process (AHP) algorithm and showed in a network and feedback system. It creates the feedback relationship to AHP to resolve the dependence problems of multi-criteria.

Recently, a number of studies in the field of social sciences have found that the characteristics of the internal complex correlation in many decision-making issues are unable to express satisfactorily with a hierarchical, linear model way because of mutual effect and dependence relationships rather than the up-down linear relationships, meaning they are network-like relationships (Saaty 1996; Saaty, Takizawa 1986). Accordingly, ANP is proposed 
to solve such problems (Sangari et al. 2015; Lee, Kim 2000; Meade, Sarkis 1998; Meade, Presley 2002).

Saaty also indicated that the mutual effect relationships of the dependence of groups and factors are able to analyze by graphics, and that the dependence relationships and interactive relationships are able to represent by arrows (Saaty 1996; Saaty 1999) as shown in Figure 4.

The factors presented in the above ANP network diagram, can be indicated by a supermatrix (Fig. 5). The supermatrix lists the groups and factors on the left side and above the matrix. The supermatrix assembles of matrices, and the sub-matrices are constituted by eigenvectors through the pairwise comparison in between factors (Fig. 5), $W_{1}, W_{2}, \ldots, W_{n n}$ refer to the eigenvectors through the calculation of the pairwise comparison. The blank, or 0 , the groups or factors are mutually independent in the supermatrix, thereby permitting the assessment of the factors in outer/inner dependence. The dependence of outer layer is the mutual influencing relationship of the groups, while the dependence of inner layer refers to the mutual relationships of factors in the same group. Hence, in making decisions, the most reliable results are fund via the ANP method.

The ANP methodology can be applied to determine optimal alternative issues, and it is able to consider the mutual dependence relationships of real problem in between various issues and factors. Many researchers believe that the ANP methodology is extended by the

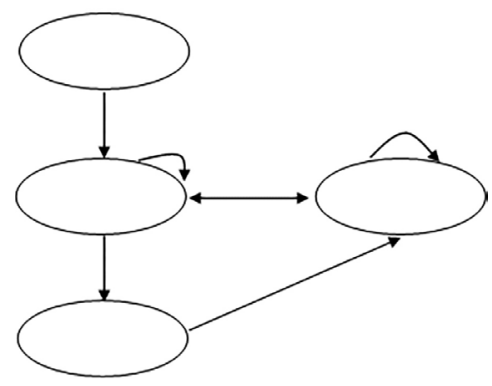

Fig. 4. ANP Network Conceptual Diagram Source: Saaty (1996)

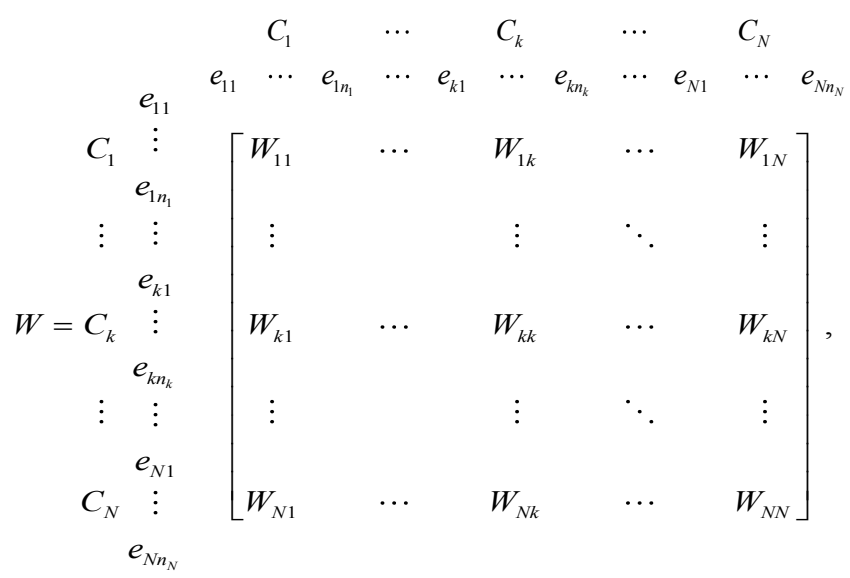

Fig. 5. Supermatrix

Source: Saaty (1996) 
AHP methodology and that it can be separate four processes comprising the architecture formation and research problem, the mutually dependent groups' pairwise comparison, the supermatrix formation and the final optimum alternative selection (Meade, Sarkis 1999; Saaty 1996). The ANP processes construction program is shown below:

\section{Step 1: Construction of a model and problem building}

The research problem should be broken down into linear, rational steps. Using the appropriate methodology, we are able obtain suggestions of experts via brainstorming or other models. If mutual effect is able to identify in between groups, such effect is the dependence of outer. If the factors of various groups are mutually effect, such effect is the dependence of inner. The overall architecture of the decision issue can thus be structured from this data.

\section{Step 2: Pair-wise comparisons matrices and eigen vectors}

Using the pairwise comparison is to compare the groups and factors in problem, and the processes involves two stages, the groups pairwise comparison and the factors pairwise comparison contained in the groups. The pairwise comparison of factors are able to further divide into the pairwise comparison within the same group and the factors pairwise comparison of different groups. With an Eigen vectors we are able to determine from the comparison model as the supermatrix values, so as to explain the dependence and synthesis weights of the groups.

\section{Step 3: Supermatrix structuring}

Supermatrix is an instrument that can resolve the various groups and factors dependence of a system more effectively. Supermatrix consists of multiple sub-matrices, and each submatrix involves the interactive relationships of factors of the groups and the pairwise comparison with other factors of the group. As for the each sub-matrix results, the Eigen vector calculated through pairwise comparison is used as the sub-matrix weight to constitute the supermatrix. If the factors of the matrix mutually depend on each other, the outcome will be a fixed convergence result through multiple multiplications of the matrix, and the extreme will be constant. The supermatrix consists of various determination standards, which are in turn included various factors. Each supermatrix result consists of sub-matrices. It involves the various groups' pairwise comparison and the comparison of groups of mutual dependence. Any group or factor without the relationships of feedback can be indicated by 0 .

The ANP calculation process involves three matrices: the first, produces the unweighted matrix; the second, produces the weighted matrix through unweighted matrix. Finally, the last produces the limit matrix by weighted matrix. The unweighted matrix is acquired by means of the original pairwise comparison. The results of weighted matrix is multiplication of the weight of the same factor with the weight of relevant group in the network model. If the sum of the columns value in unweighted matrix is 1 , which is not an unweighted matrix. The limit matrix is to achieve the value of each column is equal by multiplication of the weighted matrix. Saaty proposed the ANP calculation processes, if it is irreducible for the supermatrix $W$, then the supermatrix all columns will have the same values to achieve convergence. 


\section{Step 4: Select the optimal alternatives}

In accordance with that the supermatrix calculations, the results of weights are able to select the optimal alternatives.

As described in this part, the ANP is a MCDM tool that is via the experts' reasoning, knowledge as well as experience. The ANP is able to act as a valuable support for decisionmaking problems including both the attributes of the tangible and the intangible that are related to the model under study. The ANP method depends on the eliciting managerial inputs process and permits for structured communication within the administrators. Therefore, the ANP is able to act as a qualitative instrument for optimal decision issues.

There are many scholars has been applied the ANP algorithm to some parts. Sarkis and Sunderraj (2002) applied the ANP methodology to evaluate the qualitative and quantitative criteria for hub location on Digital Equipment Corporation. Aragones-Beltran et al. (2014) used AHP and ANP model to select the investment projects of solar-thermal power plant. Zaim et al. (2014) proposed an ANP framework to rank the technical characteristics of product. Theiben and Spinler (2014) developed an evaluation model to measure the optimal partner of supplier for implementing the collaborative CO2 reduction. Greco et al. (2013) used the ANP tool to evaluate tangible and intangible assets. However, so far, few researchers have utilized the ANP method for evaluating the optimal CO to the financial institution when financier provide the SCF services.

\section{Empirical case}

This paper developed groups and factors to assess the optimal CO in smartphone industry SC for financier and procedures as shown in Figure 6. The evaluation framework is developed via the modify Delphi method to determine the excellent CO through the software of super decision. The framework for measuring the excellent $\mathrm{CO}$ includes the following procedures:

\section{Step 1: Construction of a model and problem building}

In the light of Ali-Yrkko et al. (2011) and Linden et al. (2009), a general consensus in specialists have to achieve to construct an architecture. The final objective of determining the optimal CO in smartphone business SC for financial sector may implemented, followed by three-evaluation groups, eleven factors and finally the alternatives (Fig. 6).

The paper applied the model of Delphi for identifying the evaluation factors. Due to the factors, this paper interviewed 11 experts because the scholars have suggested specialists' number should be between 10 and 30 (Parente, Anderson-Parente 1987; Brooks 1979; Murry, Hammons 1995). Adopting the model of Delphi and specialist interviews, this paper determined the evaluation factors using four core operations in Taiwan smartphone industry SC as the theme for framework construction. There are several rounds of inquiry, feedback as well as arguments from the previous rounds in the specialist interviews on Delphi method characteristic. The subjects may even be changed, and the responses remain anonymous (Linstone, Turoff 1975). Thus, this paper applied the model of Delphi, and the outcomes are statistically significant. 


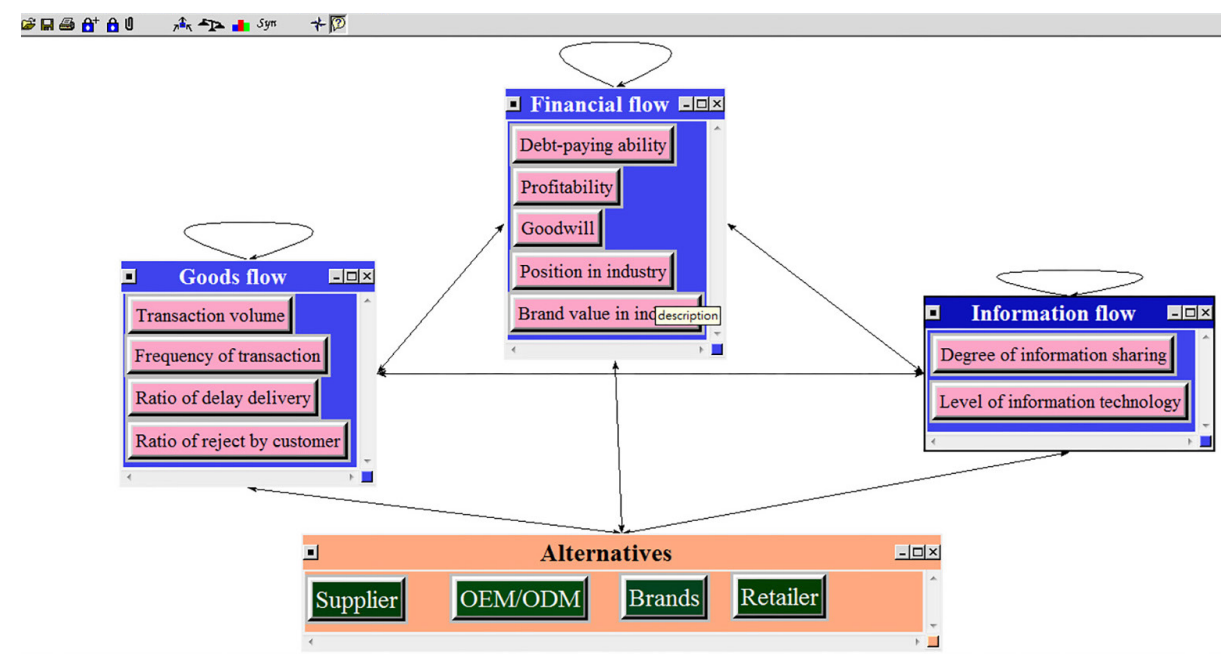

Fig. 6. Network structure to evaluate the optimal CO in smartphone SC for financier

Collecting the factors by a previous literature review and specialist interviews, and applied a Likert 7-point dimensions to score, ranging from very important (7) to very unimportant (1). After the scores were obtained, a test for consistency was executed based on quartile deviation to classification the groups. Deleting the groups with a result of 4.00 or below as well as a quartile deviation (QD) of below 1.00; on the contrary, it can be retained.

As the amount of data is a large set, this part use the Transaction value (TV) as an example to depict the details.

The Delphi survey score of expert 1 to expert 11 are as follows: 5, 6, 5, 6, 6, 6, 5, 6, 6, 6 and 7, respectively. The method is as follows: Firstly, calculate the average important index (AVII) from these results. Secondly, adopt the rank from the set which for the new set is 5, $5,5,6,6,6,6,6,6,6$ and 7, respectively. Finally, compute the Q1 and Q3 to evaluate the real results of $\mathrm{QD}$. The QD process in the factor of TV is as shown below:

$$
\begin{aligned}
& \mathrm{AVII}=\frac{5+6+5+6+6+6+5+6+6+6+7}{11}=5.81 \\
& \mathrm{Q} 1=\frac{11+1}{4}=3=>5 ; \\
& \mathrm{Q} 3=\frac{3(11+1)}{4}=9=>6 ; \\
& \mathrm{QD}=\frac{6-5}{2}=0.5 .
\end{aligned}
$$

The result of QD in the TV factor is 0.5 . Therefore, the factor of TV is retained in this research model.

The evaluation groups and factors utilized to determine the $\mathrm{CO}$ are defined as follows:

I. Goods flow (GF) includes four sub-criteria, e.g. all of transaction volume, frequency of transaction, ratio of delay delivery and ratio of reject by customer. 
- Transaction volume (TV): The total amount of transactions completed and logged in a specific time period.

- Frequency of transaction (FT): The number of occurrences of a transaction in a given time period.

- Ratio of delay delivery (RDD): The number of transactions where delivery is delayed due to problems unrelated to logistics compared to the number of transactions where the delivery is completed in the agreed upon time frame

- Ratio of reject by customer (RRC): The number of transactions where delivery is accepted by the customer compared to the number of transactions where the delivery is rejected by the customer.

II. Financial flow (FF) includes five sub-criteria, e.g. debt-paying ability, profitability, goodwill, position in industry and brand value in industry.

- Debt-paying ability (DA): The ability of the company to repay its debt obligations and remain liquid.

- Profitability (PA): The company's income after input costs, expenses and other obligations are paid.

- Goodwill (GW): A value the company has that's beyond its assets and liabilities.

- Position in industry (PII): A qualitative assessment of where a company stands in the specific industry relative to other operations in the supply chain.

- Brand value in industry (BVI): A qualitative assessment of a company's brand when compared to others in the industry.

III. Information flow (IF) includes three sub-criteria, e.g. degree of information sharing (DIS), level of information technology and degree of integrating in all of enterprise information systems (EIS).

- Degree of information sharing (DIS): The level of sharing transaction records between all members of the supply chain.

- Level of information technology (LIT): The degree to which a company integrates efficiency increasing computerized systems.

\section{Step 2: Pair-wise comparisons matrices and eigenvectors}

The eigenvectors of 11 factors match the above characteristics with each questionnaires building a pair-wise comparison of the factors and determining those relative values. The relative values provided by specialists are aggregated through the algorithm of geometric mean method. The eigenvectors of these 11 factors are shown in Table 1 as well as the groups are shown in Table 2.

\section{Step 3: Supermatrix structuring}

On the basis of the commentaries of specialist, interdependence of inner; the dependencies of the relationship in the model is acquired and the Figure 6 is depicts the dependencies of each group and factors. The weights acquired from pair-wise comparisons formed a matrix. If the eigenvector weight of groups are 0 that the groups are independent. The 
dependence of inner within the factors is calculated next. The relationships within factors is depicted in Figure 6. The weights of inner dependence relationship is listed on Table 3.

Table 1. Eigenvectors (weights) of 11 factors for alternatives

\begin{tabular}{|c|c|c|c|c|}
\hline & Brands & OEM/ODM & Retailer & Supplier \\
\hline BVI & 0.275 & 0.277 & 0.303 & 0.286 \\
\hline DA & 0.196 & 0.173 & 0.187 & 0.181 \\
\hline GW & 0.164 & 0.137 & 0.069 & 0.138 \\
\hline PA & 0.322 & 0.295 & 0.365 & 0.349 \\
\hline PII & 0.043 & 0.118 & 0.076 & 0.046 \\
\hline FT & 0.077 & 0.142 & 0.129 & 0.214 \\
\hline RDD & 0.427 & 0.367 & 0.376 & 0.334 \\
\hline RRC & 0.415 & 0.303 & 0.302 & 0.307 \\
\hline TV & 0.081 & 0.188 & 0.193 & 0.145 \\
\hline DIS & 0.581 & 0.602 & 0.597 & 0.583 \\
\hline LIT & 0.419 & 0.398 & 0.403 & 0.417 \\
\hline
\end{tabular}

Table 2. The comparisons and eigenvectors (weights) of 3 groups

\begin{tabular}{|c|c|c|c|}
\hline & FF & GF & IF \\
\hline FF & 1.000 & 2.023 & 7.298 \\
\hline GF & 0.494 & 1.000 & 3.607 \\
\hline IF & 0.137 & 0.277 & 1.000 \\
\hline Eigenvectors & 0.613 & 0.303 & 0.084 \\
\hline
\end{tabular}

Table 3. Inner dependence matrix of 11 factors

\begin{tabular}{|c|c|c|c|c|c|c|c|c|c|c|c|}
\hline & BVI & DA & GW & PA & PII & FT & RDD & RRC & TV & DIS & LIT \\
\hline BVI & 0.000 & 0.249 & 0.325 & 0.373 & 0.373 & 0.289 & 0.322 & 0.331 & 0.332 & 0.299 & 0.336 \\
\hline DA & 0.204 & 0.000 & 0.197 & 0.238 & 0.104 & 0.116 & 0.186 & 0.196 & 0.184 & 0.186 & 0.177 \\
\hline GW & 0.188 & 0.179 & 0.000 & 0.223 & 0.096 & 0.109 & 0.046 & 0.037 & 0.056 & 0.136 & 0.039 \\
\hline PA & 0.465 & 0.406 & 0.386 & 0.000 & 0.427 & 0.405 & 0.331 & 0.404 & 0.389 & 0.364 & 0.431 \\
\hline PII & 0.143 & 0.166 & 0.092 & 0.166 & 0.000 & 0.081 & 0.115 & 0.032 & 0.039 & 0.015 & 0.017 \\
\hline FT & 0.069 & 0.085 & 0.126 & 0.122 & 0.086 & 0.000 & 0.301 & 0.122 & 0.241 & 0.124 & 0.117 \\
\hline RDD & 0.398 & 0.394 & 0.381 & 0.384 & 0.352 & 0.377 & 0.000 & 0.567 & 0.452 & 0.374 & 0.378 \\
\hline RRC & 0.346 & 0.353 & 0.335 & 0.325 & 0.397 & 0.339 & 0.372 & 0.000 & 0.307 & 0.333 & 0.309 \\
\hline TV & 0.187 & 0.168 & 0.158 & 0.169 & 0.165 & 0.284 & 0.326 & 0.311 & 0.000 & 0.169 & 0.196 \\
\hline DIS & 0.663 & 0.631 & 0.557 & 0.652 & 0.612 & 0.591 & 0.608 & 0.704 & 0.632 & 0.000 & 1.000 \\
\hline LIT & 0.337 & 0.369 & 0.443 & 0.348 & 0.388 & 0.409 & 0.392 & 0.296 & 0.368 & 1.000 & 0.000 \\
\hline
\end{tabular}

\section{Step 4: Select the optimal alternatives}

The supermatrix permits for the decomposition of interdependence between the factors of this system. This can be considered a partitioned matrix, as each sub-matrix is constituted by the vectors acquired from the pair-wise comparison. The Table 4 is to show the 
supermatrix inserted in the relative weights and matrices acquired. Given the supermatrix involves interactions among groups and because, there is dependence of inner in groups and factors, summing up the eigenvector of each factors in columns unnecessarily equal one. In Table 5, transformed first to be stochastic that is a weighted supermatrix. After the weighted process in the supermatrix, the supermatrix is then increased to adequate large power to achieve the convergence. The present supermatrix achieved convergence as well as reached a distinct eigenvector. The results of final limit matrix is shown in Table 6. The supermatrix of limit is column stochastic and indicates that the final weights for groups and factors. In Table 7, illustrates the outcomes of synthesis regarding measure the optimal CO of smartphone industry SC as follows: Supplier (0.080), Brands (0.060), OEM/ODM (0.039) and Retailer (0.021). Thus, the sequential weights of the four operations are Supplier $>$ Brands $>$ OEM/ $\mathrm{ODM}>$ Retailer and the sequential of 11 factors' weights are DIS $>\mathrm{PA}>\mathrm{RDD}$ and so on. Hence, the final results of the ANP framework demonstrate that the optimal CO for financier of smartphone industry SC is Supplier, which means when a potential financiers wants to provide SCF services to smartphone industry SC, it should focus on the "supplier" firm and then the $\mathrm{CO}$ can provide the shipment records to financier that would result in the delivery of credit, records in transaction or invoice and so on to their downstream (OEM/ODM, Brands and retailer) companies. These activities not only can improve the accounts payable financing efficiency for firms downstream of the Supplier company in smartphone industry $\mathrm{SC}$ ecosystem. It can upgrade the operating income, operating scale, market share, services and innovation commodity etc. for the financier.

However, implementation of the SCF concept can upgrade the financial flow for smartphone industry SC and improve the operation for the financier. But, the financier must consider the many risks in implementation. From the three flows of smartphone SCM, some of the key sub-criteria are "DIS" and "PA", which mean when the financier provides the SCF to smartphone industry SC ecosystem, the DIS and PA are the most important. From DIS aspect, that means the level of transaction records between all members of the supply chain. Namely, the information transparency of GF and FF have to more clearly through $\mathrm{CO}$ to other members in smartphone industry SC ecosystem. There are many operation risks in a SC ecosystem when the DIS is unclearly from CO to members. That risks are not only decrease the operation efficiency for smartphone industry SC but also the financier will reduce the loan level of SCF service. Thus, it cannot improve the smallmedium size firms by CO in SC ecosystem. Another aspect is PA, which means company's income after input costs, expenses and other obligations are paid. This criterion is to point out the important of profitability for the company. It cannot enhance the financial efficiency for small-medium size firms when the PA of CO in SC is low. Because the lower PA financial institution will narrow the level of lending, PA is an important index of financial constitution for CO. Therefore, smartphone industry SC members ought to focus on these indicates' performance.

Consequently, this results of the ANP-based process illustrates that the financier evaluate the CO in SCF service for smartphone industry SC is "Supplier" when it plans to provide the SCF to smartphone industry SC. Thus, the integration of core operation in smartphone industry SC and SCF ecosystem results as shown in Figure 7. 


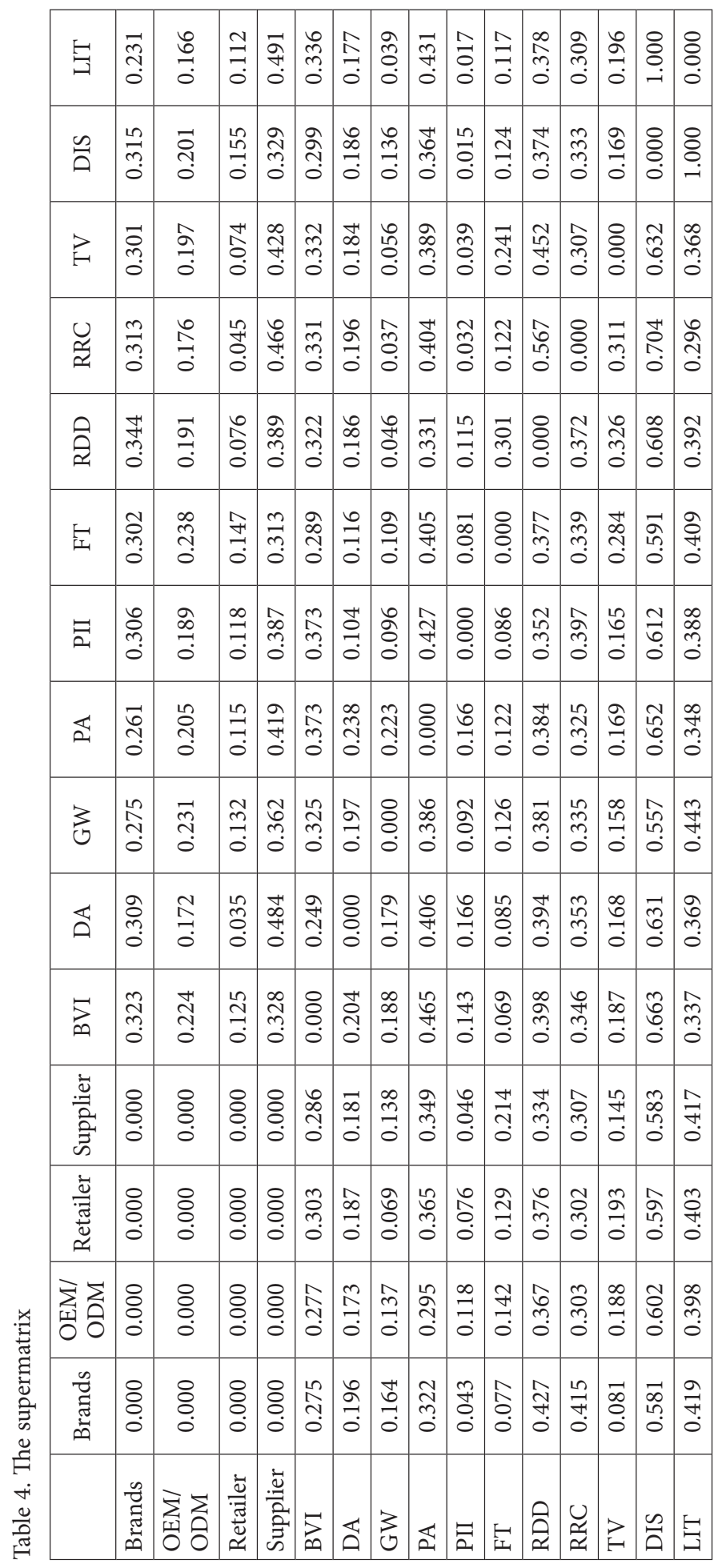




\begin{tabular}{|c|c|c|c|c|c|c|c|c|c|c|c|c|c|c|c|c|}
\hline 兒 & $\begin{array}{l}n \\
0 \\
0\end{array}$ & 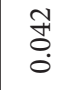 & \begin{tabular}{|c|}
$\infty$ \\
$\stackrel{1}{0}$ \\
0 \\
0
\end{tabular} & $\stackrel{\widetilde{I}}{\stackrel{1}{n}}$ & $\begin{array}{l}\stackrel{1}{\infty} \\
0 \\
0 \\
0\end{array}$ & J & & $\begin{array}{l}0 \\
0 \\
0 \\
0\end{array}$ & $\begin{array}{l}\infty \\
0 \\
0 \\
0 \\
0\end{array}$ & $\begin{array}{l}+ \\
\\
0 \\
0\end{array}$ & さे & $\begin{array}{l}2 \\
\stackrel{2}{0} \\
0 \\
0\end{array}$ & No & & & 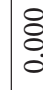 \\
\hline$\tilde{\overrightarrow{0}}$ & $\begin{array}{l}0 \\
0 \\
0\end{array}$ & $\begin{array}{l}\circ \\
\stackrel{0}{0} \\
0\end{array}$ & $\begin{array}{l}\hat{\vartheta} \\
\hat{\tilde{\theta}} \\
\dot{0}\end{array}$ & $\begin{array}{l}0 \\
0 \\
0 \\
0 \\
0\end{array}$ & 辇 & 方 & & 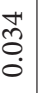 & $\begin{array}{l}\vec{a} \\
0 \\
0\end{array}$ & $\begin{array}{l}+ \\
\\
0 \\
0\end{array}$ & $\begin{array}{l}\vec{\sigma} \\
\ddot{0}\end{array}$ & $\begin{array}{l}+ \\
0 \\
0 \\
0 \\
0\end{array}$ & $\begin{array}{l}m \\
\infty \\
0 \\
0 \\
0\end{array}$ & $\stackrel{F}{F}$ & & \\
\hline$\vec{z}$ & $\begin{array}{l}n \\
\hat{\sigma} \\
0 \\
0\end{array}$ & शे. & $\begin{array}{l}\sigma \\
\ddot{\sigma} \\
\dot{0}\end{array}$ & 응 & $\begin{array}{l}\text { m } \\
\stackrel{0}{0} \\
0\end{array}$ & J & & $\begin{array}{l}\overrightarrow{+} \\
\stackrel{0}{0} \\
\dot{0}\end{array}$ & $\begin{array}{l}\hat{a} \\
\dot{o} \\
0 \\
0\end{array}$ & $\begin{array}{l}\circ \\
\stackrel{0}{0} \\
0\end{array}$ & $\begin{array}{l}\stackrel{0}{0} \\
0 \\
0 \\
0\end{array}$ & $\stackrel{m}{=}$ & No & ஓ & $\begin{array}{l}\infty \\
\stackrel{\infty}{n} \\
0\end{array}$ & \\
\hline 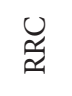 & $\begin{array}{l}\infty \\
0 \\
0 \\
0 \\
0\end{array}$ & $\begin{array}{l}\text { H } \\
\text { Oे } \\
\dot{0}\end{array}$ & $\begin{array}{l}\overrightarrow{1} \\
0 \\
0 \\
0\end{array}$ & $\stackrel{ }{\exists}$ & $\begin{array}{l}\mathscr{m} \\
0 \\
0 \\
0\end{array}$ & g & & $\begin{array}{l}2 \\
\dot{0} \\
\dot{0}\end{array}$ & $\begin{array}{l}\overrightarrow{0} \\
\overrightarrow{0} \\
\end{array}$ & $\begin{array}{l}\infty \\
\stackrel{0}{0} \\
0 \\
0\end{array}$ & $\begin{array}{l}\overrightarrow{0} \\
\ddot{0} \\
0\end{array}$ & $\underset{\mathcal{I}}{\stackrel{\mathcal{O}}{0}}$ & $\begin{array}{l}8 \\
8 \\
0 \\
0\end{array}$ & $\begin{array}{l}\infty \\
\stackrel{\infty}{0} \\
0\end{array}$ & م. & \\
\hline 宅 & $\begin{array}{l}0 \\
0 \\
0 \\
0 \\
0\end{array}$ & 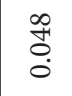 & $\begin{array}{l}0 \\
0 \\
0 \\
0\end{array}$ & ồ & $\begin{array}{l}\ddot{\infty} \\
\stackrel{0}{0} \\
\dot{0}\end{array}$ & 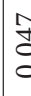 & & 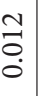 & $\begin{array}{l}\infty \\
\infty \\
0 \\
0 \\
0\end{array}$ & $\begin{array}{l}\stackrel{\text { वे }}{0} \\
\stackrel{0}{0}\end{array}$ & 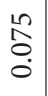 & $\begin{array}{l}8 \\
\\
0 \\
0\end{array}$ & $\frac{n}{\partial}$ & $\begin{array}{l}\mathcal{1} \\
0 \\
0 \\
0\end{array}$ & $\stackrel{N}{i}$ & \\
\hline 喪 & 足 & $\begin{array}{l}8 \\
\stackrel{0}{\circ} \\
0\end{array}$ & $\begin{array}{c}\hat{\sigma} \\
\tilde{o} \\
0\end{array}$ & 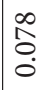 & No & à & & $\begin{array}{l}\widehat{a} \\
0 \\
0\end{array}$ & $\begin{array}{c}0 \\
-1 \\
0\end{array}$ & $\begin{array}{l}\stackrel{0}{1} \\
\text { O̦ } \\
\stackrel{0}{0}\end{array}$ & $\begin{array}{l}0 \\
\\
0 \\
0 \\
0\end{array}$ & $\begin{array}{l}+ \\
8 \\
0 \\
0\end{array}$ & $\begin{array}{l}1 \\
\infty \\
0 \\
0 \\
0\end{array}$ & $\overrightarrow{\hat{O}}$ & $\stackrel{\infty}{+}$ & 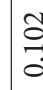 \\
\hline 元 & Oे & $\begin{array}{l}\text { पे } \\
\text { Oे. }\end{array}$ & $\begin{array}{l}0 \\
0 \\
0 \\
0 \\
0\end{array}$ & $\begin{array}{l}\hat{a} \\
\hat{\sigma} \\
0\end{array}$ & g̊ & 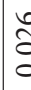 & & 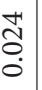 & \begin{tabular}{c}
$\hat{0}$ \\
\hdashline \\
0
\end{tabular} & \begin{tabular}{l}
8 \\
\hdashline \\
\hdashline \\
0
\end{tabular} & 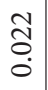 & \begin{tabular}{|c|}
$\infty$ \\
0 \\
0 \\
0 \\
0
\end{tabular} & $\stackrel{\partial}{\circ}$ & F & $\stackrel{\substack{n \\
0}}{\circ}$ & \\
\hline 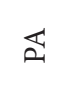 & $\begin{array}{l}n \\
0 \\
0 \\
0\end{array}$ & 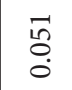 & 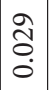 & 웅 & gू & ह & & \begin{tabular}{l}
0 \\
\multirow{2}{0}{} \\
0 \\
0 \\
0
\end{tabular} & $\begin{array}{l}0 \\
8 \\
0 \\
0\end{array}$ & 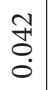 & $\begin{array}{l}\vec{\delta} \\
0 \\
0\end{array}$ & $\begin{array}{l}0 \\
8 \\
0 \\
0\end{array}$ & $\begin{array}{l}\vec{\infty} \\
0 \\
0 \\
0\end{array}$ & 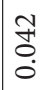 & r & 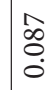 \\
\hline 芘 & $\begin{array}{l}0 \\
0 \\
0 \\
0\end{array}$ & 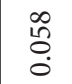 & $\begin{array}{l}m \\
\tilde{o} \\
0 \\
0\end{array}$ & $\vec{\sigma}$ & $\begin{array}{l}\vec{\infty} \\
0 \\
0\end{array}$ & $\stackrel{g}{g}$ & & $\begin{array}{l}8 \\
\vdots \\
\vdots\end{array}$ & $\begin{array}{l}\hat{a} \\
0 \\
0\end{array}$ & $\begin{array}{c}\tilde{O} \\
\tilde{O} \\
0\end{array}$ & $\begin{array}{c}\tilde{\sigma} \\
0 \\
0\end{array}$ & $\begin{array}{l}n \\
2 \\
0 \\
0\end{array}$ & $\mid \begin{array}{l}+ \\
0 \\
0 \\
0 \\
0\end{array}$ & 웅 & $\stackrel{9}{\stackrel{m}{0}}$ & 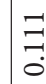 \\
\hline$\overleftrightarrow{\Delta}$ & $\begin{array}{l}1 \\
\text { D̂. } \\
0 \\
0\end{array}$ & $\begin{array}{l}\text { for } \\
\text { Oे } \\
\dot{0}\end{array}$ & $\mid \begin{array}{l}0 \\
\dot{0} \\
0 \\
0\end{array}$ & $\vec{I}$ & ర్ & ¿ & & $\begin{array}{l}2 \\
\stackrel{2}{0} \\
0 \\
0\end{array}$ & $\begin{array}{c}1 \\
0 \\
0 \\
0\end{array}$ & $\begin{array}{l}\tilde{y} \\
\stackrel{3}{0} \\
0\end{array}$ & $\overrightarrow{\tilde{\sigma}}$ & $\begin{array}{l}2 \\
\dot{\partial} \\
0 \\
0\end{array}$ & $\mid \begin{array}{l}\infty \\
0 \\
0 \\
0 \\
0\end{array}$ & ક̊ & 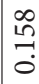 & \\
\hline 召 & $\begin{array}{l}\overrightarrow{0} \\
0 \\
0 \\
0\end{array}$ & $\begin{array}{l}0 \\
\text { Lे } \\
0 \\
0\end{array}$ & $\begin{array}{l}\overrightarrow{0} \\
0 \\
0\end{array}$ & $\begin{array}{l}0 \\
0 \\
0 \\
0 \\
0\end{array}$ & \& & 5 & & 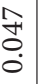 & $\begin{array}{l}0 \\
\cdots \\
0\end{array}$ & \begin{tabular}{|l|}
0 \\
$\tilde{\delta}$ \\
0 \\
0
\end{tabular} & $\begin{array}{l}1 \\
0 \\
0 \\
0\end{array}$ & $\begin{array}{l}8 \\
0 \\
0\end{array}$ & $\mid \begin{array}{l}0 \\
\infty \\
0 \\
0\end{array}$ & 余 & $\stackrel{8}{\circ}$ & 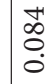 \\
\hline 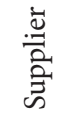 & $\begin{array}{l}8 \\
8 \\
0 \\
0\end{array}$ & \begin{tabular}{l}
8 \\
\hdashline \\
0
\end{tabular} & $\begin{array}{l}8 \\
0 \\
0 \\
0\end{array}$ & $\begin{array}{l}8 \\
0 \\
0\end{array}$ & $\stackrel{2}{1}$ & $\bar{z}$ & & $\begin{array}{l}0 \\
\infty \\
0 \\
0 \\
0\end{array}$ & \begin{tabular}{l}
$\overrightarrow{1}$ \\
\multirow{2}{0}{}
\end{tabular} & $\begin{array}{c}\infty \\
\tilde{O} \\
0 \\
0\end{array}$ & $\begin{array}{l}n \\
0 \\
0 \\
0\end{array}$ & $\begin{array}{l}\overrightarrow{0} \\
\overrightarrow{0} \\
0\end{array}$ & 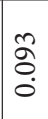 & $\begin{array}{l}\text { J } \\
0 \\
0\end{array}$ & शे & 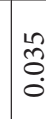 \\
\hline$\frac{\ddot{\Xi}}{\widetilde{\pi}}$ & $\begin{array}{l}8 \\
8 \\
0 \\
0\end{array}$ & $\begin{array}{l}8 \\
: \\
0\end{array}$ & $\begin{array}{l}8 \\
0 \\
0 \\
0\end{array}$ & 官 & $\begin{array}{l}\infty \\
\infty \\
0\end{array}$ & 4 & & 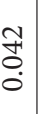 & $\begin{array}{c}\stackrel{+}{J} \\
\stackrel{\sim}{0}\end{array}$ & 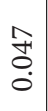 & ڤે & $\underset{\square}{ \pm}$ & 官 & $\begin{array}{l}\infty \\
1 \\
0 \\
0 \\
0\end{array}$ & 웅 & 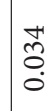 \\
\hline$\sum_{\substack{1 \\
0}} \sum_{0}$ & $\begin{array}{l}8 \\
8 \\
0 \\
0\end{array}$ & $\begin{array}{l}8 \\
\stackrel{0}{0} \\
0\end{array}$ & $\begin{array}{l} \\
\\
\\
\\
\end{array}$ & ○ & $\stackrel{?}{1}$ & ฮ & & $\begin{array}{l}+ \\
\infty \\
0 \\
0 \\
0\end{array}$ & $\begin{array}{l}\vec{\infty} \\
\overrightarrow{0} \\
\end{array}$ & $\begin{array}{l}\mathbb{N} \\
\stackrel{\Delta}{0} \\
0\end{array}$ & $\begin{array}{l}m \\
\stackrel{9}{0} \\
0 \\
0\end{array}$ & $\exists$ & 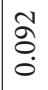 & 苍 & 능 & 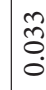 \\
\hline \multirow[t]{2}{*}{ 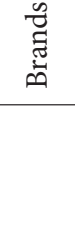 } & $\begin{array}{l}8 \\
8 \\
0 \\
0\end{array}$ & $\begin{array}{l}8 \\
8 \\
\circ\end{array}$ & \begin{tabular}{|l|} 
\\
\\
0 \\
0 \\
\end{tabular} & ஓ & ô & $\Omega$ & & $\begin{array}{l}\overrightarrow{0} \\
\overrightarrow{0} \\
0\end{array}$ & $\begin{array}{c}\hat{a} \\
\overrightarrow{0}\end{array}$ & 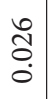 & $\begin{array}{l}0 \\
\delta \\
0\end{array}$ & $\begin{array}{c}\stackrel{\overbrace{}}{1} \\
\stackrel{0}{0}\end{array}$ & 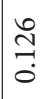 & $\stackrel{2}{\mathscr{C}}$ & 官 & 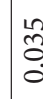 \\
\hline & 苟 & $\sum_{\text {至 }}^{i}$ & 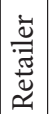 & 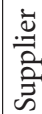 & & & & 3 & 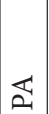 & $\bar{\Xi}$ & $\stackrel{-H}{I}$ & 宝 & 崩 & $\vec{z}$ & $\stackrel{\mathscr{A}}{ }$ & \\
\hline
\end{tabular}




\begin{tabular}{|c|c|c|c|c|c|c|c|c|c|c|c|c|c|c|c|}
\hline$\stackrel{G}{G}$ & $\begin{array}{l}8 \\
0 \\
0 \\
0\end{array}$ & ڤે & $\vec{\delta}$ & $\begin{array}{l}0 \\
\& \\
0 \\
0\end{array}$ & $\begin{array}{l}\sigma \\
\delta \\
0\end{array}$ & $\begin{array}{l}\infty \\
0 \\
0 \\
0 \\
0\end{array}$ & है & $\begin{array}{l}0 \\
0 \\
0\end{array}$ & ¿্. & $\begin{array}{l}0 \\
0 \\
0 \\
0\end{array}$ & $\begin{array}{l}2 \\
\stackrel{2}{0} \\
0\end{array}$ & 离 & fo & ำ & ö \\
\hline$\tilde{\theta}$ & $\begin{array}{l}8 \\
0 \\
0\end{array}$ & $\begin{array}{l}\hat{\tilde{y}} \\
\dot{0}\end{array}$ & $\overrightarrow{\widetilde{\sigma}}$ & $\begin{array}{l}8 \\
\& \\
0 \\
0\end{array}$ & $\begin{array}{l}\sigma \\
\delta \\
0 \\
0\end{array}$ & $\begin{array}{l}\infty \\
0 \\
0 \\
0 \\
0\end{array}$ & $\begin{array}{l}\hat{\tilde{z}} \\
\dot{0}\end{array}$ & $\begin{array}{l}0 \\
0 \\
0 \\
0\end{array}$ & 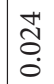 & $\begin{array}{l}0 \\
\tilde{0} \\
0 \\
0\end{array}$ & $\begin{array}{l}2 \\
2 \\
0 \\
0\end{array}$ & $\begin{array}{l}\vec{\infty} \\
0 \\
0 \\
0\end{array}$ & $\begin{array}{l}q \\
\stackrel{9}{0} \\
\dot{0}\end{array}$ & 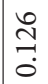 & बे \\
\hline$\vec{B}$ & $\begin{array}{l}8 \\
0 \\
0\end{array}$ & ڤે & $\vec{a}$ & $\begin{array}{l}0 \\
0 \\
0 \\
0\end{array}$ & ô & $\begin{array}{l}\infty \\
0 \\
0 \\
0 \\
0\end{array}$ & ڤે & 官 & 范 & 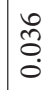 & $\begin{array}{l}20 \\
\text { gे } \\
0\end{array}$ & $\begin{array}{l}\overrightarrow{0} \\
\stackrel{0}{0} \\
0\end{array}$ & $\begin{array}{l}\stackrel{g}{0} \\
\text { ப. }\end{array}$ & $\stackrel{0}{\stackrel{0}{1}}$ & $\vec{\sigma}$ \\
\hline 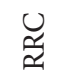 & : & $\begin{array}{l}\hat{\tilde{O}} \\
\dot{0}\end{array}$ & $\overrightarrow{\tilde{\sigma}}$ & $\begin{array}{l}0 \\
8 \\
0 \\
0\end{array}$ & $\begin{array}{l}\sigma \\
\delta \\
0 \\
0\end{array}$ & $\begin{array}{l}\infty \\
0 \\
0 \\
0 \\
0\end{array}$ & $\begin{array}{l}\hat{\tilde{\delta}} \\
\dot{0}\end{array}$ & 咅 & 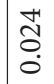 & $\begin{array}{l}0 \\
0 \\
0 \\
0\end{array}$ & 응 & 离 & $\begin{array}{l}\text { fे } \\
\text { ப. } \\
0\end{array}$ & I & है \\
\hline ลิ & : & ڤે & $\vec{\delta}$ & $\begin{array}{l}0 \\
0 \\
0 \\
0\end{array}$ & $\begin{array}{l}\sigma \\
\delta \\
0 \\
0\end{array}$ & $\begin{array}{l}\infty \\
0 \\
0 \\
0 \\
0\end{array}$ & 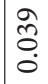 & $\begin{array}{l}2 \\
0 \\
0 \\
0\end{array}$ & đू. & $\begin{array}{l}0 \\
\tilde{ల} \\
0 \\
0\end{array}$ & $\begin{array}{l}2 \\
\hat{g} \\
0 \\
0\end{array}$ & $\begin{array}{l}\vec{\infty} \\
0 \\
0 \\
0\end{array}$ & 㝘 & 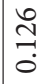 & ô \\
\hline 藏 & $\begin{array}{l}8 \\
0 \\
0\end{array}$ & ڤે & $\vec{\sigma}$ & $\begin{array}{l}0 \\
0 \\
0 \\
0\end{array}$ & ô & $\begin{array}{l}\infty \\
0 \\
0 \\
0 \\
0\end{array}$ & 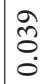 & 官 & ¿্. & $\begin{array}{l}0 \\
0 \\
0 \\
0\end{array}$ & 응 & $\begin{array}{l}\vec{\infty} \\
0 \\
0\end{array}$ & $\begin{array}{l}\stackrel{g}{0} \\
0 \\
0\end{array}$ & i & है \\
\hline 至 & : & ڤે & $\vec{\delta}$ & $\begin{array}{l}0 \\
0 \\
0 \\
0\end{array}$ & $\begin{array}{l}\sigma \\
\delta \\
0 \\
0\end{array}$ & $\begin{array}{l}\infty \\
0 \\
0 \\
0 \\
0\end{array}$ & 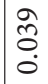 & $\begin{array}{l}2 \\
0 \\
0 \\
0\end{array}$ & đू. & $\begin{array}{l}0 \\
\tilde{ల} \\
0 \\
0\end{array}$ & $\begin{array}{l}2 \\
\hat{g} \\
0 \\
0\end{array}$ & $\begin{array}{l}\vec{\infty} \\
0 \\
0 \\
0\end{array}$ & 㝘 & 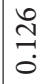 & ô \\
\hline$\overleftrightarrow{\Omega}$ & $\begin{array}{l}8 \\
0 \\
0\end{array}$ & ڤે & $\vec{\sigma}$ & $\begin{array}{l}0 \\
0 \\
0 \\
0\end{array}$ & ô & $\begin{array}{l}\infty \\
0 \\
0 \\
0 \\
0\end{array}$ & 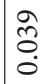 & 官 & ¿্. & $\begin{array}{l}0 \\
0 \\
0 \\
0\end{array}$ & 응 & $\begin{array}{l}\vec{\infty} \\
0 \\
0\end{array}$ & $\begin{array}{l}\stackrel{g}{0} \\
0 \\
0\end{array}$ & i & है \\
\hline 3 & : & ڤે & $\vec{\sigma}$ & $\begin{array}{l}0 \\
0 \\
0 \\
0\end{array}$ & ô & $\begin{array}{l}\infty \\
0 \\
0 \\
0 \\
0\end{array}$ & है & $\begin{array}{l}2 \\
0 \\
0 \\
0\end{array}$ & 范 & $\begin{array}{l}0 \\
0 \\
0 \\
0\end{array}$ & 응 & 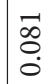 & $\begin{array}{l}\stackrel{9}{0} \\
\dot{0}\end{array}$ & $\stackrel{0}{1}$ & वृ \\
\hline$\overleftrightarrow{a}$ & : & ڤે & $\vec{\sigma}$ & $\begin{array}{l}0 \\
0 \\
0 \\
0\end{array}$ & $\begin{array}{l}\tilde{\sigma} \\
\delta \\
0\end{array}$ & $\begin{array}{l}\infty \\
0 \\
0 \\
0 \\
0\end{array}$ & है & $\begin{array}{l}0 \\
0 \\
0 \\
0\end{array}$ & 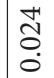 & 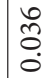 & 응 & $\begin{array}{l}\overrightarrow{0} \\
0 \\
0\end{array}$ & $\begin{array}{l}\stackrel{9}{0} \\
0 \\
0\end{array}$ & $\stackrel{0}{1}$ & $\vec{g}$ \\
\hline 齐 & : & ڤે & $\vec{\delta}$ & $\begin{array}{l}0 \\
0 \\
0 \\
0\end{array}$ & $\begin{array}{l}\sigma \\
\delta \\
0 \\
0\end{array}$ & $\begin{array}{l}\infty \\
0 \\
0 \\
0 \\
0\end{array}$ & 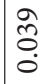 & $\begin{array}{l}2 \\
0 \\
0 \\
0\end{array}$ & đू. & $\begin{array}{l}0 \\
\tilde{ల} \\
0 \\
0\end{array}$ & $\begin{array}{l}2 \\
\hat{g} \\
0 \\
0\end{array}$ & $\begin{array}{l}\vec{\infty} \\
0 \\
0 \\
0\end{array}$ & 㝘 & 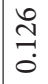 & ô \\
\hline 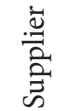 & $\begin{array}{l}0 \\
0 \\
0\end{array}$ & ڤેळે & $\vec{\sigma}$ & $\begin{array}{l}0 \\
0 \\
0 \\
0\end{array}$ & $\begin{array}{l}\sigma \\
\hat{\sigma} \\
0\end{array}$ & $\begin{array}{l}\infty \\
0 \\
0 \\
0 \\
0\end{array}$ & है & 辛 & 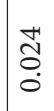 & 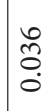 & 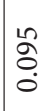 & 离 & 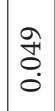 & $\stackrel{0}{\stackrel{2}{1}}$ & बे \\
\hline 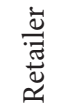 & : & ळે. & $\overrightarrow{\widetilde{\sigma}}$ & $\begin{array}{l}8 \\
\infty \\
0 \\
0\end{array}$ & ô & $\begin{array}{l}\infty \\
0 \\
0 \\
0 \\
0\end{array}$ & है & $\begin{array}{l}2 \\
0 \\
0 \\
0\end{array}$ & ¿ू. & $\begin{array}{l}0 \\
\tilde{ల} \\
0 \\
0\end{array}$ & $\begin{array}{l}2 \\
\stackrel{2}{2} \\
0 \\
0\end{array}$ & $\vec{~}$ & 它 & 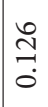 & बे \\
\hline$\sum_{\substack{1 \\
0}} \sum_{0}$ & $\begin{array}{l}8 \\
0 \\
0\end{array}$ & ळे. & $\vec{\delta}$ & $\begin{array}{l}0 \\
0 \\
0 \\
0\end{array}$ & ô. & $\begin{array}{l}\infty \\
0 \\
0 \\
0 \\
0\end{array}$ & ڤે & oे & 芯 & 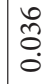 & 늠 & $\begin{array}{l}\vec{\infty} \\
0 \\
0\end{array}$ & $\begin{array}{l}\text { fे } \\
\text {. } \\
0\end{array}$ & i & है \\
\hline \multirow[t]{2}{*}{ 节 } & : & ळે & $\overrightarrow{\tilde{D}}$ & $\begin{array}{l}0 \\
\stackrel{0}{0} \\
0 \\
0\end{array}$ & oू & $\begin{array}{l}\infty \\
0 \\
0 \\
0 \\
0\end{array}$ & ڤે & 음 & స్ & $\begin{array}{l}0 \\
0 \\
0 \\
0\end{array}$ & 응 & $\vec{\infty}$ & $\begin{array}{l}\text { f } \\
\text { o } \\
0\end{array}$ & $\stackrel{2}{\stackrel{2}{c}}$ & $\bar{\partial}$ \\
\hline & 泀 & 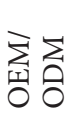 & 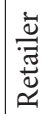 & $\begin{array}{l}\ddot{\bar{\Xi}} \\
\overline{2} \\
\stackrel{2}{\Xi}\end{array}$ & 召 & 㟔 & 齐 & $\overleftarrow{\Sigma}$ & $\bar{\Sigma}$ & 㤐 & 穴 & 亲 & $\vec{z}$ & $\mathscr{A}$ & 昀 \\
\hline
\end{tabular}


Table 7. The results of the ANP

\begin{tabular}{|l|c|c|}
\hline \multicolumn{1}{|c|}{ Name } & Normalized By Cluster & Limiting \\
\hline Supplier & 0.400 & 0.080 \\
\hline Brands & 0.298 & 0.060 \\
\hline OEM/ODM & 0.197 & 0.039 \\
\hline Retailer & 0.104 & 0.021 \\
\hline DIS & 0.580 & 0.126 \\
\hline PA & 0.339 & 0.109 \\
\hline RDD & 0.363 & 0.095 \\
\hline BVI & 0.285 & 0.092 \\
\hline LIT & 0.420 & 0.091 \\
\hline RRC & 0.312 & 0.081 \\
\hline DA & 0.180 & 0.058 \\
\hline TV & 0.187 & 0.049 \\
\hline GW & 0.122 & 0.039 \\
\hline FT & 0.139 & 0.036 \\
\hline PII & 0.075 & 0.024 \\
\hline
\end{tabular}

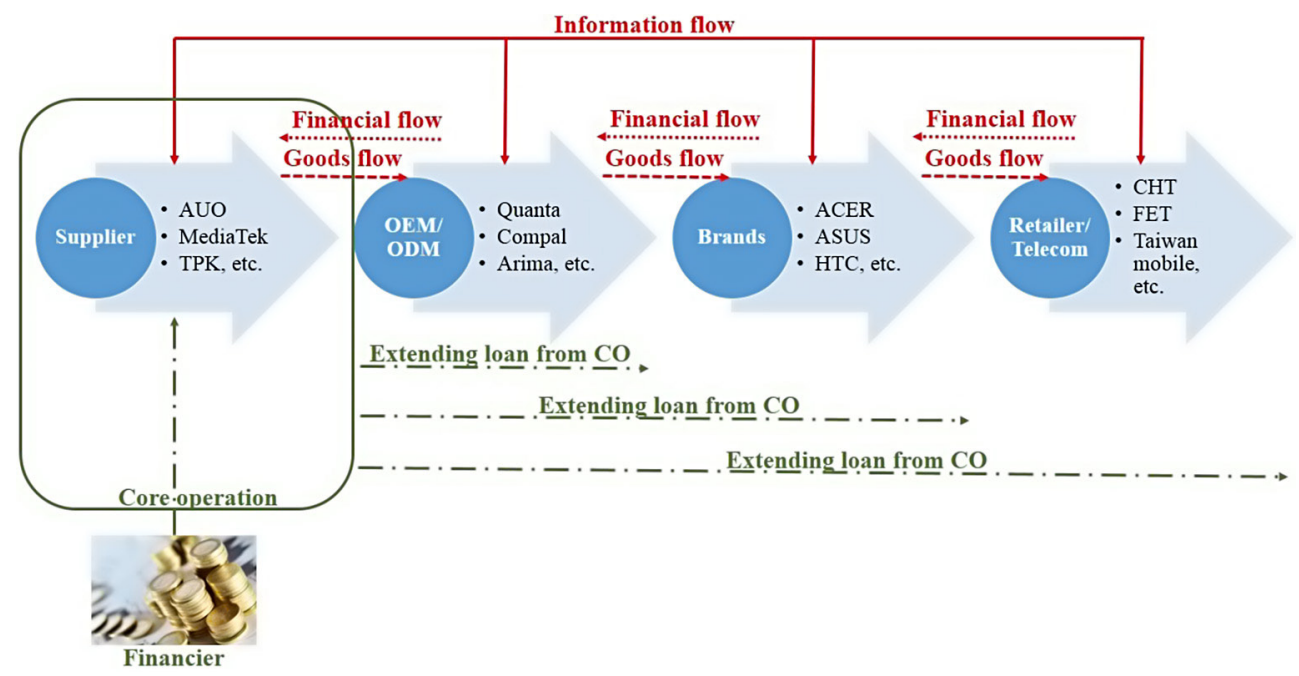

Fig. 7. The core operation of a smartphone industry SC on a SCF ecosystem 


\section{Conclusions}

SCF is new type of financial service that can be enhance the financial efficiency of an SC. The key concept of SCF is the delivery of credit. Using the transaction records from the CO to the members, the financier can be provide a higher level of cash flow to the ecosystem. In addition, financial sectors would be upgrading their operations through utilizing SCF. Even though SCF services can help the financial sectors to improve their operations, but there are many risks implied in SCF activities from $\mathrm{CO}$ to relative members.

Because various financial ecosystem concerns in a SC have interrelate relationship, using the hierarchical concept is unable to resolve the barrier. A literature review shows that the SCF structure not only reduces loan barriers for SMEs but also improves the financial efficiency in their SC and enhances the income or operations for financial sectors that implement the SCF activities. Typically throughout the supply chain the SMEs will be the individual component suppliers (as this sector has the lowest margins) so having the additional capital provided by the SCF would allow these firms to scale up their operations and become more efficient. Nevertheless, applying with implementing the optimal CO in smartphone industry SC is a highly intricate topic for financial institution managers, administrators as well as decision-makers.

As such, this study proposes a methodology for applying the ANP in the decision-making process to assess $\mathrm{CO}$ for acquiring the optimal operation in smartphone industry SC for a financier. This methodology includes the formation of supermatrix that assign the interrelated among groups within the research framework and the supermatrix of limit that the relative weights is obtained for the groups and factors. This can be considered critical the decision-maker of the financial sectors usually lack of the procedures of objective decisionmaking or measurement interdependent groups and factors to obtain the optimal $\mathrm{CO}$ in a SC and there are highly risks for providing the SCF into the SC process, the ANP is able to resolve the characteristic of interdependence in all factors becomes an valid instrument for the managers to acquire an accurate alternative.

This study show that the optimal operation in the smartphone industry supply chain is "supplier" and the key criteria are "Degree of information sharing", "Profitability" and "Ratio of delay delivery". That means the efficiency of information sharing and profitability on the "supplier" operation is higher than other members in the smartphone industry supply chain and the ratio of delay delivery is lower than others. The degree of information sharing includes information such as inventory data, ordering data, transaction data and manufacturing times etc. Thus, the sharing on supplier is more transparently than manufacturer, brand and retailer in smartphone industry supply chain. The profitability is an important factor on any lending issues. In this case, the architecture of smartphone industry supply chain is a highly complex environment. All of the materials in midstream and downstream have to be processed through the supplier. In other words, supplier phase is only one channel on purchase activities for midstream and downstream. Hence, the profitability perspective in smartphone industry supply chain, supplier is higher than others. The supplier phase of smartphone industry is originally in that supply chain process. They have lower waiting time in prepare feed than other phase. Moreover, the capability of information sharing is also bet- 
ter than other phases in their supply chain. Accordingly, the ratio of delay delivery is also an important criterion in optimal CO of SCF evaluation.

Hence, the presented ANP-based framework on decision making is able to help by prioritizing and weighing the complex scenarios which would help the financier provide the SCF service involved in assessing the CO. This model can provide academic support to administrators for financiers with a valuable guide for measuring the CO of smartphone industry SC to acquire the optimal solution in SCF service.

\section{References}

Adhikary, P.; Kundu, S.; Roy, P. K.; Mazumdar, A. 2013. Optimum selection of hydraulic turbine manufacturer for SHP: MCDA or MCDM tools, World Applied Sciences Journal 28(7): 914-919.

Ali-Yrkko, J.; Rouvinen, P.; Seppala, T.; Yla-Anttila, P. 2011. Who captures value in global supply chains? Case Nokia N95 Smartphone, Journal of Industry, Competition and Trade 11(3): 263-278. https://doi.org/10.1007/s10842-011-0107-4

Aragones-Beltran, P.; Chaparro-Gonzalez, F.; Pastor-Ferrando, J.; Pla-Rubio, A. 2014. An AHP/ANPbased multi-criteria decision approach for the selection of solar-thermal power plant investment projects, Energy 66: 222-238. https://doi.org/10.1016/j.energy.2013.12.016

Ashis, M. 2013. Selection of handloom fabrics for summer clothing by AHP method of multi-criteria decision making (MCDM) techniques, International Journal of Management, IT and Engineering 3(8): 265-278.

Berger, A. N.; Udell, G. F. 2006. A more complete conceptual framework for SME finance, Journal of Banking and Finance 30: 2945-2966. https://doi.org/10.1016/j.jbankfin.2006.05.008

Blackman, I. D.; Holland, C. P.; Westcott, T. 2013. Motorola’s global financial supply chain strategy, Supply Chain Management: an International Journal 18(2): 132-147. https://doi.org/10.1108/13598541311318782

Brooks, K. W. 1979. Delphi technique: expanding applications, North Central Association Quarterly 53: 377-385.

Greco, M.; Cricelli, L.; Grimaldi, M. 2013. A strategic management framework of tangible and intangible assets, European Management Journal 31(1): 55-66. https://doi.org/10.1016/j.emj.2012.10.005

Guillen, G.; Badell, M.; Puigjaner, L. 2007. A holistic framework for short-term supply chain management integrating production and corporate financial planning, International Journal of Production Economics 106: 288-306. https://doi.org/10.1016/j.ijpe.2006.06.008

He, X.; Tang, L. 2012. Exploration on building of visualization platform to innovate business operation pattern of supply chain finance, Physics Procedia 33: 1886-1893. https://doi.org/10.1016/j.phpro.2012.05.298

Kristofik, P.; Kok, J.; Vries, S.; Hoff, J. S. 2012. Financial supply chain management-challenges and obstacles, ACRN Journal of Entrepreneurship Perspectives 1(2): 132-143.

Linden, G.; Kraemer, K. L.; Dedrick, J. 2009. Who captures value in a global innovation network? The case of Apple's iPod, Communications of the ACM 52(3): 140-144. https://doi.org/10.1145/1467247.1467280

Linstone, H. A.; Turoff, M. 1975. The Delphi method: techniques and applications. Addison-Wesley Publishing Company. 620 p.

Liu, S. 2007. Development status and risk prevention of supply chain finance, Journal of China Logistics and Purchasing 7: 68-69. 
Lee, J. W., \& Kim, S. H. (2000). Using analytic network process and goal programming for interdependent information system project selection, Computers \& Operations Research 27(4): 367-382. https://doi.org/10.1016/S0305-0548(99)00057-X

MAZARS. 2011. Supply chain finance: the key link to an efficient supply chain. France [online], [cited 30 May 2014]. Available from Internet: http://www.mazars.ie/mazarspage/download/78136/2023824/ file/Supply-Chain-Finance-07-11-11.pdf

Meade, L. M.; Presley, A. 2002. R\&D project selection using the analytic network process, IEEE Transactions on Engineering Management 49(1): 59-66. https://doi.org/10.1109/17.985748

Meade, L. M.; Sarkis, J. 1998. Strategic analysis of logistics and supply chain management systems using the analytic network process, Transportation Research Part E: Logistics and Transportation Review 34(3): 201-215. https://doi.org/10.1016/S1366-5545(98)00012-X

Meade, L. M.; Sarkis, J. 1999. Analyzing organizational project alternatives for agile manufacturing processes-an analytical network approach, International Journal of Production Research 37(2): 241-261. https://doi.org/10.1080/002075499191751

More, D.; Basu, P. 2013. Challenges of supply chain finance: a detailed study and a hierarchical model based on the experiences of an Indian firm, Business Process Management Journal 19(4): 624-647. https://doi.org/10.1108/BPMJ-09-2012-0093

Murry, J. W.; Hammons, J. O. 1995. Delphi: a versatile methodology for conducting qualitative research, The Review of Higher Education 18: 423-436. https://doi.org/10.1353/rhe.1995.0008

Parente, F.; Anderson-Parente, J. 1987. Delphi inquiry systems. Wright, G.; Ayton, P. (Eds.). NY: John Wiley and Sons.

Pfohl, H.; Gomm, M. 2009. Supply chain finance: optimizing financial flows in supply chains, Logistics Research 1: 149-161. https://doi.org/10.1007/s12159-009-0020-y

Pourahmad, A.; Hosseini, A.; Banaitis, A.; Nasiri, H.; Banaitiene, N.; Tzeng, G. H. 2015. Combination of fuzzy-AHP and DEMATEL-ANP with GIS in a new hybrid MCDM model used for the selection of the best space for leisure in a blighted urban site, Technological and Economic Development of Economy 21(5): 773-796. https://doi.org/10.3846/20294913.2015.1056279

Randal, W. S.; Farris, M. T. 2009. Supply chain financing: using cash-to-cash variables to strengthen the supply chain, International Journal of Physical Distribution and Logistics Management 39(8): 669-689. https://doi.org/10.1108/09600030910996314

Saaty, T. L. 1980. The analytic hierarchy process. New York: McGraw Hill.

Saaty, T. L. 1996. Decision making with dependence and feedback: the analytic network process. Pittsburgh: RWS Publications.

Saaty, T. L. 1999. Fundamentals of the analytic network process. Kobe Japan: ISAHP.

Sangari, M. S.; Razmi, J; Zolfaghari, S. 2015. Developing a practical evaluation framework for identifying critical factors to achieve supply chain agility, Measurement 62: 205-214. https://doi.org/10.1016/j.measurement.2014.11.002

Saaty, T. L.; Takizawa, M. 1986. Dependence and independence: from linear hierarchies to nonlinear networks, European Journal of Operational Research 26(2): 229-237.

Sarkis, J.; Sunderraj, R. 2002. Hub location at Digital Equipment Corporation: a comprehensive analysis of qualitative and quantitative factors, European Journal of Operational Research 137: 336-347. https://doi.org/10.1016/S0377-2217(01)00138-2

Shahin, A.; Pourhamidi, M. 2013. Proposing a comprehensive and hierarchic framework for prioritizing Isfahan brands using AHP and TOPSIS approaches, International Journal of Applied Decision Sciences 6(2): 160-185. https://doi.org/10.1504/IJADS.2013.053272

Simchi-Levi, D.; Kamisky, P.; Simchi-Levi, E. 2000. Designing and management the supply chain. Concepts, Strategies, and Case Studies Irwin, McGraw-Hill, New York. 
Sung, W. C. 2001. Application of Delphi method, a qualitative and quantitative analysis, to the healthcare management, Journal of Healthcare Management 2(2): 11-19.

Theiben, S.; Spinler, S. 2014. Strategic analysis of manufacturer-supplier partnerships: an ANP model for collaborative CO2 reduction management, European Journal of Operational Research 233(2): 383-397. https://doi.org/10.1016/j.ejor.2013.08.023

Tsai, H. Y.; Chang, C. W.; Lin, H. L. 2010. Fuzzy hierarchy sensitive with Delphi method to evaluate hospital organization performance, Expert Systems with Applications 37(8): 5533-5541. https://doi.org/10.1016/j.eswa.2010.02.099

Uygun, O.; Kahveci, T. C.; Taskin, H.; Piristine, B. 2015. Readiness assessment model for institutionalization of SMEs using fuzzy hybrid MCDM techniques, Computers and Industrial Engineering 88: 217-228. https://doi.org/10.1016/j.cie.2015.07.008

Wang, T.; Lan, Q.; Chu, Y. 2013. Supply chain financing model: based on China's agricultural products supply chain, in Proceedings of the $2^{\text {nd }}$ International Conference on Systems Engineering and Modeling, 153-157. https://doi.org/10.2991/icsem.2013.30

Wu, C. R.; Chang, C. W.; Lin, H. L. 2007a. An organizational performance measurement model based on AHP sensitivity analysis, International Journal of Business Performance Management 9: 77-91. https://doi.org/10.1504/IJBPM.2007.011497

Wu, C. R.; Lin, C. T.; Chen, H. C. 2007b. Evaluating competitive advantage of the location for Taiwanese hospitals, Journal of Information and Optimization Sciences 28(5): 841-868. https://doi.org/10.1080/02522667.2007.10699777

Xu, Y.; Patnayakuni, R.; Tao, F.; Wang, H. 2015. Incomplete interval fuzzy preference relations for supplier selection in supply chain management, Technological and Economic Development of Economy 21(3): 379-404. https://doi.org/10.3846/20294913.2013.876688

Yan, N.; Sun, B. 2013. Coordinating loan strategies for supply chain financing with limited credit, $O R$ Spectrum 35: 1039-1058. https://doi.org/10.1007/s00291-013-0329-4

Yan, N.; Sun, B.; Zhang, H.; Liu, C. 2016. A partial credit guarantee contract in a capital-constrained supply chain: financing equilibrium and coordinating strategy, International Journal of Production Economics 173: 122-133. https://doi.org/10.1016/j.ijpe.2015.12.005

Yazdani-Chamzini, A.; Fouladgar, M. M.; Zavadskas, E. K.; Moini, S. H. H. 2013. Selecting the optimal renewable energy using multicriteria decision making, Journal of Business Economics and Management 14(5): 957-978. https://doi.org/10.3846/16111699.2013.766257

Zaim, S.; Sevkli, M.; Camgoz-Akdag, H.; Demirel, O. F.; Yesim Yayla, A.; Delen, D. 2014. Use of ANP weighted crisp and fuzzy QFD for product development, Expert Systems with Applications 41(9): 4464-4474. https://doi.org/10.1016/j.eswa.2014.01.008 